\title{
DESIGN AND IMPACT OF USING TRICKLE IRRIGATION SYSTEM FOR GREENHOUSES IN DELTA REGION IN EGYPT

\author{
$\begin{array}{lll}\text { A. M. El Sheikha } & & \text { R. A. Hegazy } \\ & \text { D. M. El Shikha } & \end{array}$
} \\ ABSTRACT
}

Analysis and hydraulic calculations are directed to optimize a suitable design of low pressure gravity-fed water systems for greenhouses and smallholder farms. The experiment was conducted to analyze the impact of key design factors such as the required head (2, 3, 4 and $5 \mathrm{~m}$ ), emitter spacing [(0.3, 0.6, 0.9 and $1.2 \mathrm{~m}$ for in-line non-pressure compensated (INPC) emitters and 0.4, 0.7, 1.0 and 1.3 for on-line pressure compensated $(O P C)]$, discharge capacity and emitter type (INPC and $O P C)$ and their effect on the maximum lateral length (MLL) which was defined as the length with flow variation that is less than or equal to 5\% in a low-pressure gravity fed trickle system. INPC emitters had the highest effect of the head on the maximum lateral length (MLL) at all emitter spacing under study. Spacing of 1.2 and $1.3 \mathrm{~m}$ for the INPC and OPC emitters, respectively, had the highest effect on the MLL. However, the lowest values of MML were 11.96 and $17.53 \mathrm{~m}$, which were for 0.3 and $0.4 \mathrm{~m}$ spacing in INPC and OPC emitters, respectively. Also, the combine model of variables without their interactions has indicated that INPC emitters perform the highest MLL and the other variables in the model were significant. Such equations could be used to decide the MLL for a given spacing under the available head of the water supply system. In both NPC and INPC emitters, increasing the head level increased total tomato yield and there were significant decreasing in yield by increasing emitter spacing, where maximum yield was 43.6 ton/ha at $5 \mathrm{~m}$ head for INPC emitters and 44.4 ton tha at $4 \mathrm{~m}$ head for OPC emitters with emitter spacing 0.3 and $0.4 m$ respectively.

Keyword: Trickle Irrigation, Gravity-fed, Greenhouses, Smallholders, Tomato

1 Assistant Professor, Agricultural Engineering Department, Fac. of Agric, Damietta branch, Mansoura University, Egypt

2 Assistant Professor, Agricultural Engineering Department, Fac. of Agric, Kafrelsheikh University, Egypt

3 Associate Professor, Agricultural Engineering Department, Fac. of Agric, Mansoura University, Egypt 


\section{INTRODUCTION}

reating high values for agricultural crops by using low water inputs and high fertilizer efficiencies is one of the methods used in addressing the environmental and resources problems. Protected cultivation techniques including nethouse technology provide optimum environmental medium for better crop growth in order to gain maximum yield and high quality products (Harmanto et al., 2004 and Cheema et al., 2005). There is need to reduce significant energy being used to lift water for irrigation or to pump drainage water for disposal or re-use in both the old lands; of the Nile valley and delta, and those new reclaimed lands in the deserts and fringes of the Nile valley and delta (Nour El Din, 2007). In trickle irrigation, lateral length, pipe diameter, emitter spacing, ground slope, emitter flow rate, pressure head of the trickle system, emitter type and the form of the emitter are important factors considered for design of the system (Jaiswal et al., 2001).

A majority of smallholders in developing countries are deprived of this technology due to non-adaptability and cost to small land holdings. International Development Enterprises (IDE), a non-profit development organization, has overcome this problem by developing a range of small, easy-to-use, and affordable micro irrigation kits (IDE, 2010). That's why novel irrigation technologies need to be tested under local environments and particular agricultural production systems. Thus, the main challenge confronting both rain fed and irrigated agriculture is to improve water use efficiency (WUE) and sustainable water use for agriculture. Drip irrigation increased fruit yield of tomato and improved WUE due to consumption of less water (Berihun, 2011).

Irrigation requires relatively large quantities of water which is becoming increasingly scarce. On the other hand, waters of a wide range of quality can be used for irrigation by appropriately selecting crops, irrigation methods and management practices (Malash et al., 2005).

In addition to this, trickle irrigation is a highly efficient method of water application, which is also ideally suited for controlling the placement and 
supply rate of water-soluble fertilizers, in a study done by Shedeed et al., (2009), trickle irrigation recorded significantly higher total dry matter production (3.60 t/ha) and leaf area index (LAI) (3.15) over furrow irrigation.

Several design procedures and charts are already available for the forcefed trickle systems bearing a high-pressure head. Available manuals showing the performance capabilities of different emitters had a range within a high pressure head provided by a pressurized trickle system. But hydraulic calculations had not been directed to derive a suitable design procedure which enable one to manipulate the combinations of design parameters such as lateral size, form and type of emitter, discharge capacity of emitter and emitter spacing on the available low pressure head of a given gravity-fed trickle irrigation system. Such hydraulic analysis will help to achieve an emission uniformity of drippers that ultimately affect their system uniformity. Therefore, the aim of this study was to analyze the impact of key design factors such as the required head, emitter spacing, discharge capacity and emitter type and their effect on the maximum lateral length (MLL).

\section{MATERIALS AND METHODS}

\section{System design and variables}

Experiments were conducted in Delta region at the Kafr El-Sheikh Governorate during the period from April to December 2011. The experimental site was located in 31" / r'7० N 30 56'40" E zone with $3 \mathrm{~m}$ above sea level, the soil classified as clay type.

A modified cistern of $1200 \mathrm{~L}$ capacity was manufactured and divided into four different parts to give organized heights (heads) of 5, 4, 3 and $2 \mathrm{~m}$ above the ground level. The returned pressure heads of $0.5,0.40,0.25$, and 0.20 bars were acquired for heights ranging from 5 to $2 \mathrm{~m}$, respectively. Low-Density Polyethylene (LDPE) tubes of $16 \mathrm{~mm}$ diameter were used as laterals and were laid along levelled beds. Two sets of 12 
lateral lines were provided with in-line non-pressure compensated and online pressure compensated (INPC and OPC) types of emitters having discharge rates of 1 and 2 lph respectively with above mentioned pressure heads. The four non- pressure compensated emitters were spaced at 0.3 , 0.6, 0.9 and $1.2 \mathrm{~m}$ with three replicates of each. The other four pressure compensated were spaced at $0.4,0.7,1$ and $1.3 \mathrm{~m}$ with same number of replicates. Each set was operated with the four defined pressure. A screen type filter and pressure regulator were used at the head control unit to filter the water and measure the pressure, the water used for trickle irrigation was uploaded to tanks from an irrigation canal located near experimental site.

Discharge rate of each emitter was measured by volumetric method. From the measured emitter flow rates, percent flow variation of each lateral length was determined. Maximum lateral lengths (MLL) were estimated by reducing length of lateral by $1 \mathrm{~m}$ each time and measuring the flow variation till it reach $5 \%$ or less. The mean values of MLL against their treatment levels were statistically analysed. Using GLM and XLSTAT (modified packages for statistical analysis); single and complete Linear Explanatory models were derived to see the impact of each single independent input variable with other fixed input variable levels on the dependant variable (MLL) as well as the combination of the model.

\section{Greenhouse and agronomical aspects}

Seeds of tomato (Lycopersicon esculentum) Super Strain B were transplanted. Planting spacing were $0.3 \mathrm{~m}$ within rows, and spacing between rows were $0.7 \mathrm{~m}$. A combination of fertilizers (FYM at $21 \mathrm{t} \mathrm{ha}^{-1}$, vermicompost a $2 \mathrm{t} \mathrm{ha}^{-1}$ and chemical fertilizers at 150:150:250 kg N, P and $\mathrm{K} \mathrm{ha}^{-1}$ ) was applied. The greenhouse of $60 \times 40 \times 3 \mathrm{~m}$ (fig ) dimension designed as mixed Quonset and rigid frame supported by galvanized steel with metal pipe frames film plastic coverage of polyethylene (PE) was used. 


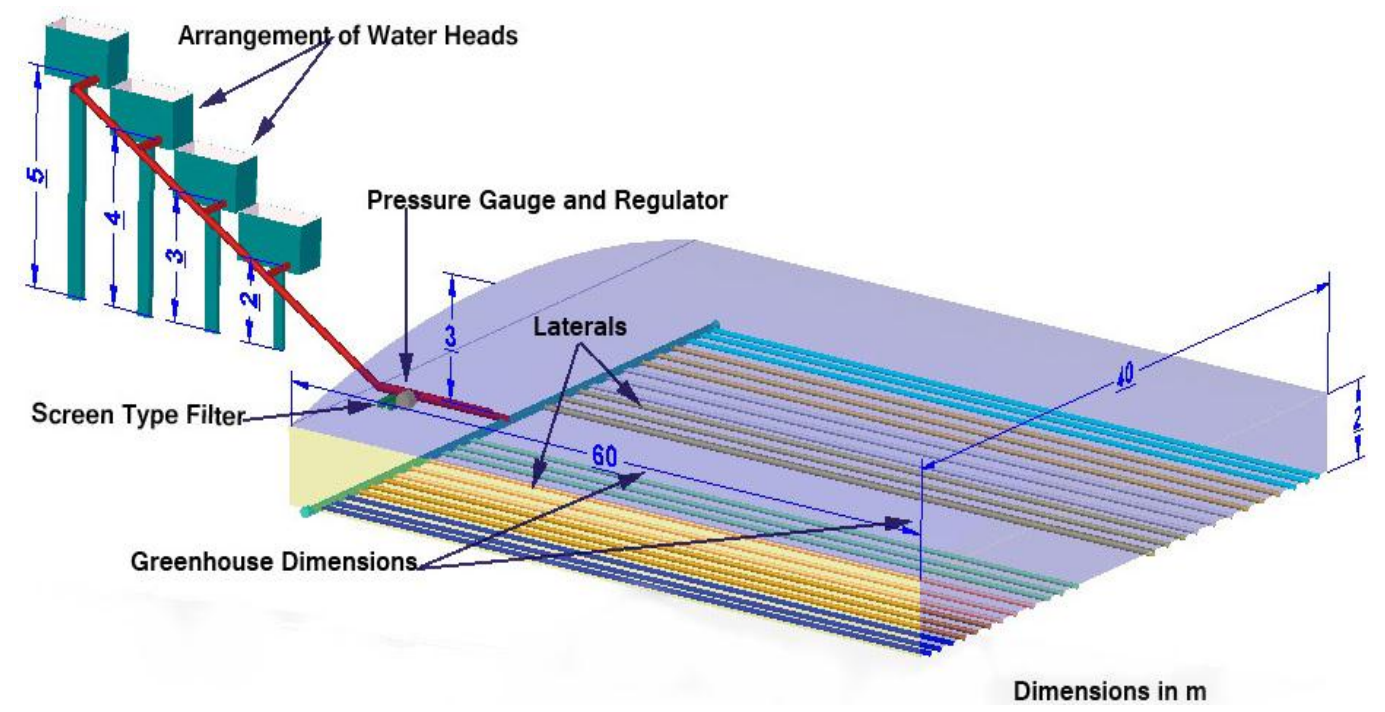

Fig. 1 Dimension of manufactured greenhouse and arrangement of water heads

\section{Data collection}

Discharge head of each emitter was measured. From the measured emitter flow rates, percent flow variation of each lateral length was determined for their respective treatment levels using the equation suggested by Bralts et al. (1982).

$$
\mathrm{q}_{\mathrm{var}}=\frac{\mathrm{q}_{\max }-\mathrm{q}_{\min }}{\mathrm{q}_{\max }} X 100 \ldots \ldots \ldots \ldots . .1
$$

Where,

$\mathrm{q}_{\text {var. }}=$ Emitter flow variation $(\%)$

$\mathrm{q}_{\text {max. }}=$ Maximum emitter discharge $(\mathrm{L} / \mathrm{h})$

$\mathrm{q}_{\text {min. }}=$ Minimum emitter discharge $(\mathrm{L} / \mathrm{h})$

\subsection{Loss of head due to friction in a pipe and friction loss}

Loss of head due to friction in a pipe $\left(\mathrm{h}_{\mathrm{f}}\right)$ between two points at a distance, 1 apart, is given by the formula (Michel, 1978)

$$
\mathrm{h}_{\mathrm{f}}=\frac{4 \mathrm{flv}}{2 \mathrm{gd}}
$$

Where,

$\mathrm{f}=$ Coefficient of friction for pipe, $\mathrm{m}$

$1=$ Length of pipe, $m$ 
$\mathrm{d}=$ Diameter of pipe, $\mathrm{m}$

$\mathrm{g}=$ Gravitational force $\mathrm{m} / \mathrm{sec}^{2}$.

$\mathrm{v}=$ Velocity, $\mathrm{m} / \mathrm{sec}$

The friction coefficient, $\mathrm{f}$ is not simply a coefficient of friction between the water and the surface of the pipe, but includes a coefficient of resistance due to eddying motion in the water itself. It further depends upon the smoothness or roughness of the pipe surface. The value of $\mathrm{f}$ is less if the pipe is new and smooth. Head losses in strainer and foot valve of a pump are obtained from the following formula

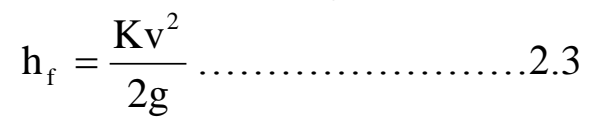

Where,

$\mathrm{h}_{\mathrm{f}}=$ Head loss due to friction, $\mathrm{m}$

$\mathrm{K}=$ Constant and equal to 0.95 and 0.80 for strainer and foot valve respectively

\subsection{Emitter flow variation and laterals aspects}

The flow conditions in the sub-main and laterals of a trickle system can be considered as steady and specially varied with lateral out flows. The degree of variation of emitter out flow can be shown by the following uniformity coefficient equation.

$$
\mathrm{C}_{\mathrm{u}}=100\left(1.0-\frac{\sum \mathrm{x}}{\mathrm{mn}}\right) \ldots \ldots \ldots \ldots \ldots \ldots . .2 .4
$$

Where,

$\mathrm{m}=$ Average value of all observations (average application rate), $\mathrm{mm}$

$\mathrm{n}=$ Total number of observation point, $\Sigma \mathrm{x}=$ Numerical deviation of individual observations from the average and application rate, $\mathrm{mm}$. A uniform coefficient of $100 \%$ is indicated of absolutely uniform application, where as the water application is less uniform with a lower $\%$. A uniformity coefficient of $85 \%$ or more is considered to be satisfactory.

Following equations can be used to estimate the head loss by friction in trickle irrigation line.

$$
\Delta \mathrm{H}=15.27 \mathrm{X} \frac{\mathrm{Q}^{1.852} \mathrm{x} \mathrm{L}}{\mathrm{D}^{4.871}} \ldots \ldots \ldots \ldots \ldots \ldots \ldots . . .5
$$

Where, 
$\Delta \mathrm{H}=$ Energy drop by friction, $\mathrm{m}$

$\mathrm{Q}=$ Total discharge in the pipe, $\mathrm{L} / \mathrm{sec}$.

$\mathrm{D}=$ Diameter of the pipe section, $\mathrm{m}$

$\mathrm{L}=$ Length of the pipe, $\mathrm{m}$

This equation is frequently used to compute the energy drop of a main line sections. Since the discharge in the line decreases with respect to the length, the total energy drop will be less than the one given in the above equation. The total energy drop, $\Delta \mathrm{H}$, for lateral or sub-main can be determined by same equation used to calculate energy drop by friction, but with taking $\mathrm{D}$ as inside diameter of lateral or sub-main and $\mathrm{L}$ is the total length of lateral or dub-main in $\mathrm{cm}$ with 5.35 constant value.

Hydraulically, the pressure variation along a lateral line will cause an emitter flow variation along the lateral. The pressure variation, $\mathrm{h}_{\mathrm{var}}$, is defined as,

$$
\mathrm{H}_{\mathrm{var}}=\frac{\mathrm{h}_{\max }-\mathrm{h}_{\min }}{\mathrm{h}_{\max }} \ldots \ldots \ldots \ldots \ldots \ldots \ldots \ldots \ldots \ldots \ldots \ldots . . .6
$$

Where,

$\mathrm{h}_{\max }=$ The maximum pressure head along the lateral or sub-main, $\mathrm{m}$

$\mathrm{h}_{\min }=$ The minimum pressure head of lateral or sub-main, $\mathrm{m}$

In trickle irrigation design, the design criteria is generally based on an emitter flow variation of less than $10 \%$ or about $20 \%$ pressure variation for lateral line; and a lateral flow variation of less than $5 \%$ or about $10 \%$ pressure variation for a sub-main. Maximum lateral length (MLL) readings were taken by reducing the length of lateral by $1 \mathrm{~m}$ at a time and noting of emitter flow variations till their respective values were less than or equal to $5 \%$. Yield of tomato of individual crop along a lateral was collected.

\section{RESULTS AND DISCUSSION}

\section{Design Factors and variables}

The key design factors were identified to keep the maximum lateral length (MLL) within 5\% flow variation as the dependent variable. The independent input variables selected for the study were emitter type (pressure compensated or non-pressure compensated type), discharge rate, pressure head of the system and emitter spacing. 


\subsection{Impact of individual input variables on MLL}

The impact of the head was observed by having the MLL as the dependant variable. The mean values of MLL increased with increasing the pressure head and the emitter spacing for both emitter types under study INPC and OPC (Table 1). The highest value of the MLL, $35.23 \mathrm{~m}$, for the INPC emitters was achieved with the $5 \mathrm{~m}$ head and $1.2 \mathrm{~m}$ emitter spacing. Also, a MLL value of $44.14 \mathrm{~m}$ was achieved with the $5 \mathrm{~m}$ head and an emitter spacing of $1.3 \mathrm{~m}$. For the same head (5 m), higher MLL was achieved with smaller emitter spacing for OPC emitter if compared to the INPC emitter (Table 1). Linear regression equations were calculated and listed in Table 2 . The equations had relatively high $\mathrm{R}^{2}$ values (that ranged from 0.75 to 0.99 ) and very low standard error. The regression equations associated with the OPC emitters were relatively high than those associated with the INPC emitter.

Table 1 Mean values of MLL under emitter type, rated discharge, head of the system and the emitter spacing.

\begin{tabular}{|c|c|c|c|c|c|c|}
\hline \multirow{2}{*}{$\begin{array}{c}\text { Emitter } \\
\text { Type }\end{array}$} & \multirow{2}{*}{$\begin{array}{c}\text { Discharge rate } \\
(\text { LPH) }\end{array}$} & \multirow{2}{*}{ Spacing (m) } & \multicolumn{4}{|c|}{ Maximum lateral length within 5\% variation } \\
& & & \multicolumn{4}{|c|}{ Head (m) } \\
\cline { 3 - 7 } & & & 2 & 3 & 4 & 5 \\
\hline INPC & 1.00 & 0.3 & 11.96 & 13.08 & 13.77 & 14.54 \\
\hline INPC & 1.00 & 0.6 & 17.36 & 22.17 & 22.44 & 25.25 \\
\hline INPC & 1.00 & 0.9 & 18.32 & 23.38 & 29.75 & 30.62 \\
\hline INPC & 1.00 & 1.2 & 20.19 & 28.16 & 31.43 & 35.23 \\
\hline OPC & 2.00 & 0.4 & 17.53 & 19.24 & 21.05 & 23.15 \\
\hline OPC & 2.00 & 0.7 & 23.44 & 25.24 & 26.56 & 32.62 \\
\hline OPC & 2.00 & 1.0 & 30.50 & 32.68 & 34.78 & 36.75 \\
\hline OPC & 2.00 & 1.3 & 35.85 & 41.50 & 39.94 & 44.14 \\
\hline
\end{tabular}


Table 2 1ndividual regression equations of heads

\begin{tabular}{|c|c|c|c|c|}
\hline $\begin{array}{c}\text { Emitter } \\
\text { Type }\end{array}$ & $\begin{array}{c}\text { Rated } \\
\text { Discharge } \\
\text { (LPH) }\end{array}$ & $\begin{array}{c}\text { Spacing } \\
\text { (m) }\end{array}$ & Regression equations & $\mathbf{R}^{2}$ \\
\hline INPC & $\mathbf{1 . 0 0}$ & 0.3 & $M L L=10.387+0.843 \mathrm{H}$ & $=0.987$ \\
\hline INPC & 1.00 & 0.6 & $M L L=13.426+2.394 \mathrm{H}$ & $=0.891$ \\
\hline INPC & 1.00 & 0.9 & $M L L=10.373+4.327 \mathrm{H}$ & $=\mathbf{0 . 9 3 3}$ \\
\hline INPC & 1.00 & 1.2 & $M L L=11.816+4.839 \mathrm{H}$ & $=\mathbf{0 . 9 5 3}$ \\
\hline OPC & 2.00 & 0.4 & $M L L=13.708+1.867 \mathrm{H}$ & $=\mathbf{0 . 9 9 7}$ \\
\hline OPC & 2.00 & 0.7 & MLL $=16.864+2.886 \mathrm{H}$ & $=\mathbf{0 . 8 7 5}$ \\
\hline OPC & 2.00 & 1.0 & $M L L=26.381+2.085 \mathrm{H}$ & $=0.999$ \\
\hline OPC & 2.00 & 1.3 & $M L L=32.199+2.331 \mathrm{H}$ & $=0.752$ \\
\hline
\end{tabular}

Data and their regression line indicated positive relationship between the emitter spacing and the MLL. The range of MLL values as affected by the emitter type and pressure head is indicated in Figures 2 and 3 respectively.

Data and regression line

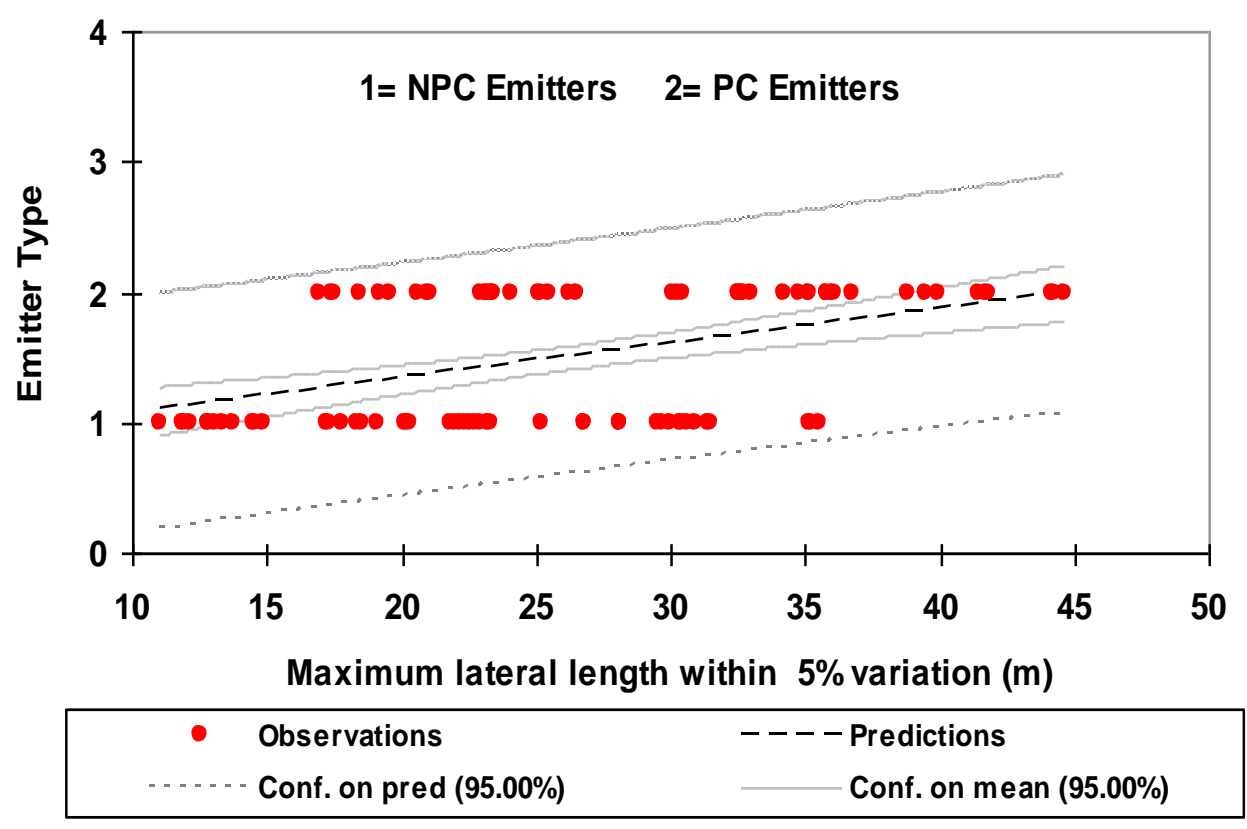

Fig. 2 Data and regression line of emitter type 


\section{Data and regression line}

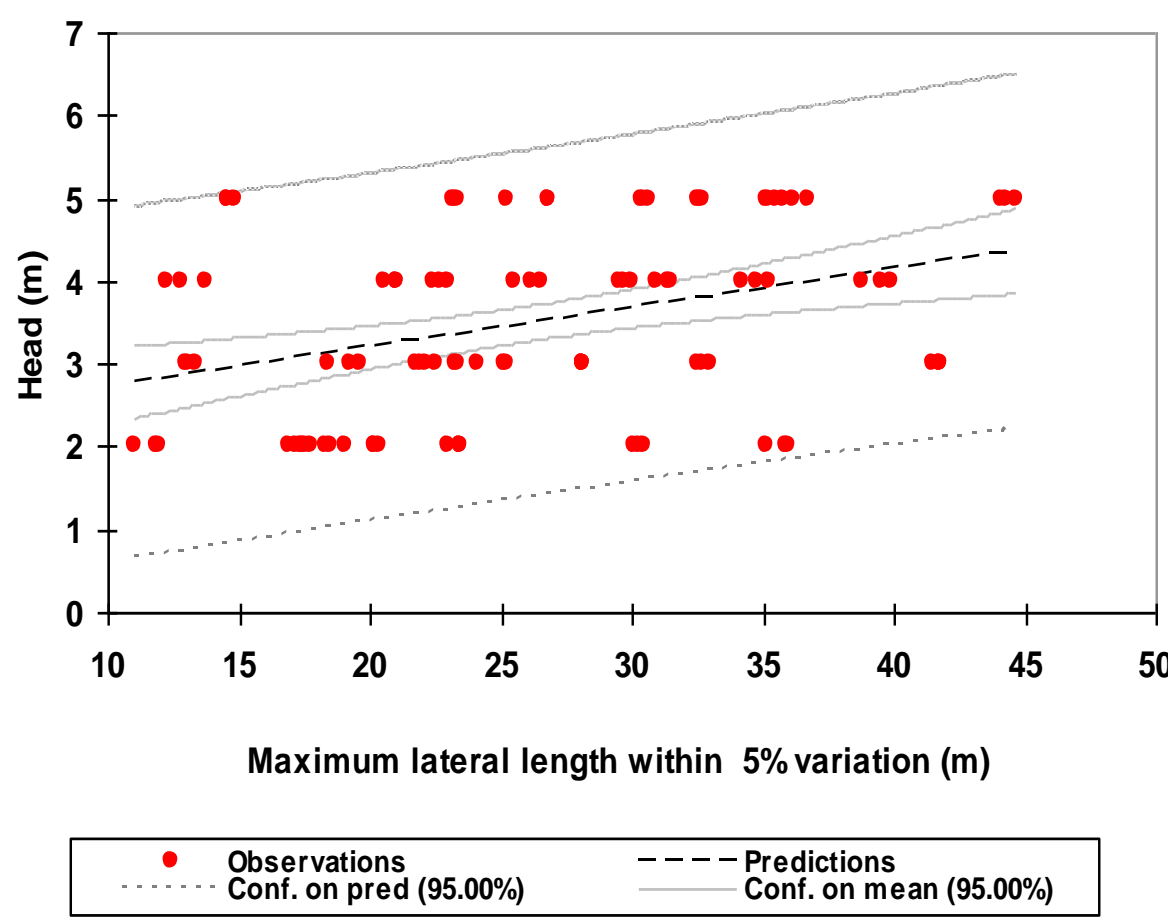

Fig. 3 Data and regression line of water head

The calculated equations could be used to decide the MLL for a given spacing under the available head of the water supply system or vice versa. At the same time, the comparative results given above on head for types of emitters will enable one to adopt the total irrigable area within the same head according to the selected crop.

According to Fig. 4 and 5, the highest effective spacing for the MLL were 1.2 and $1.3 \mathrm{~m}$ indicated by INPC and OPC emitters respectively. While the lowest values of MML were 11.96 an $17.53 \mathrm{~m}$ for 0.3 and $0.4 \mathrm{~m}$ spacing in INPC and OPC emitter respectively. 


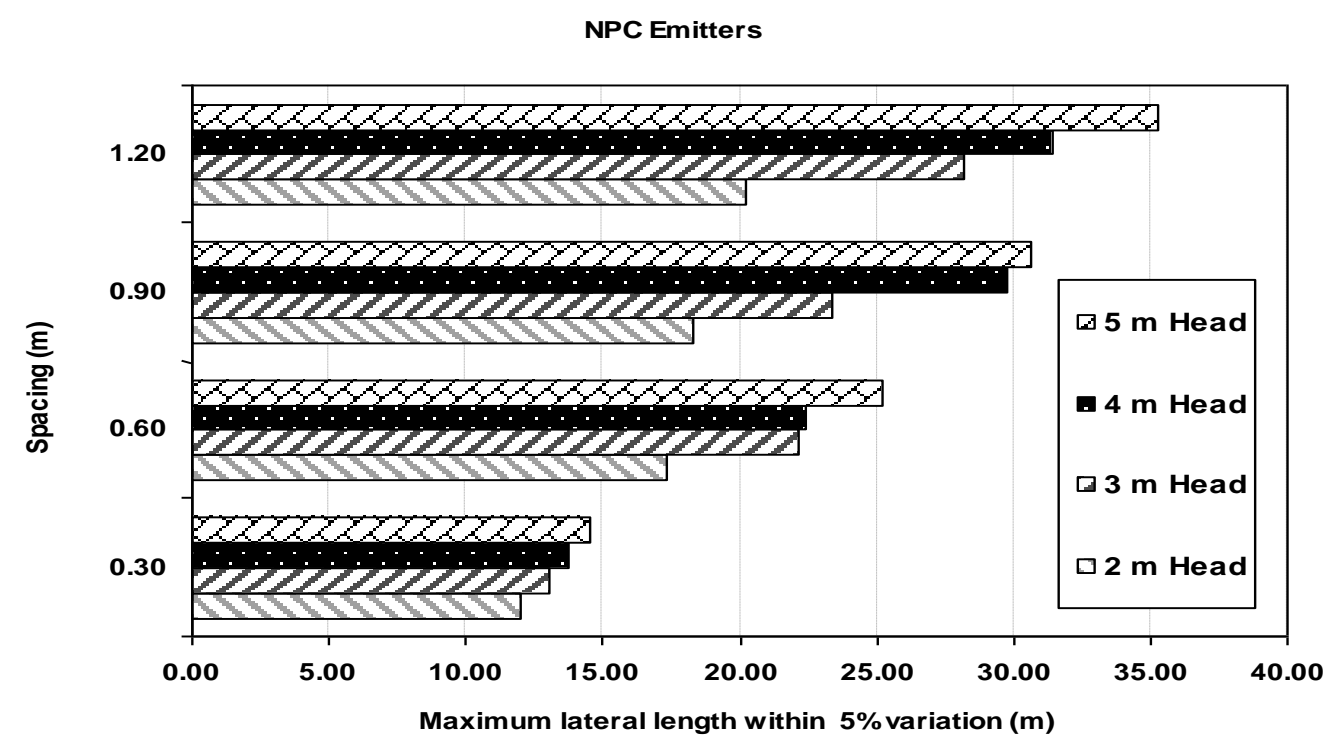

Fig. 4 Effect of Spacing on MLL - In-Line NPC Emitter

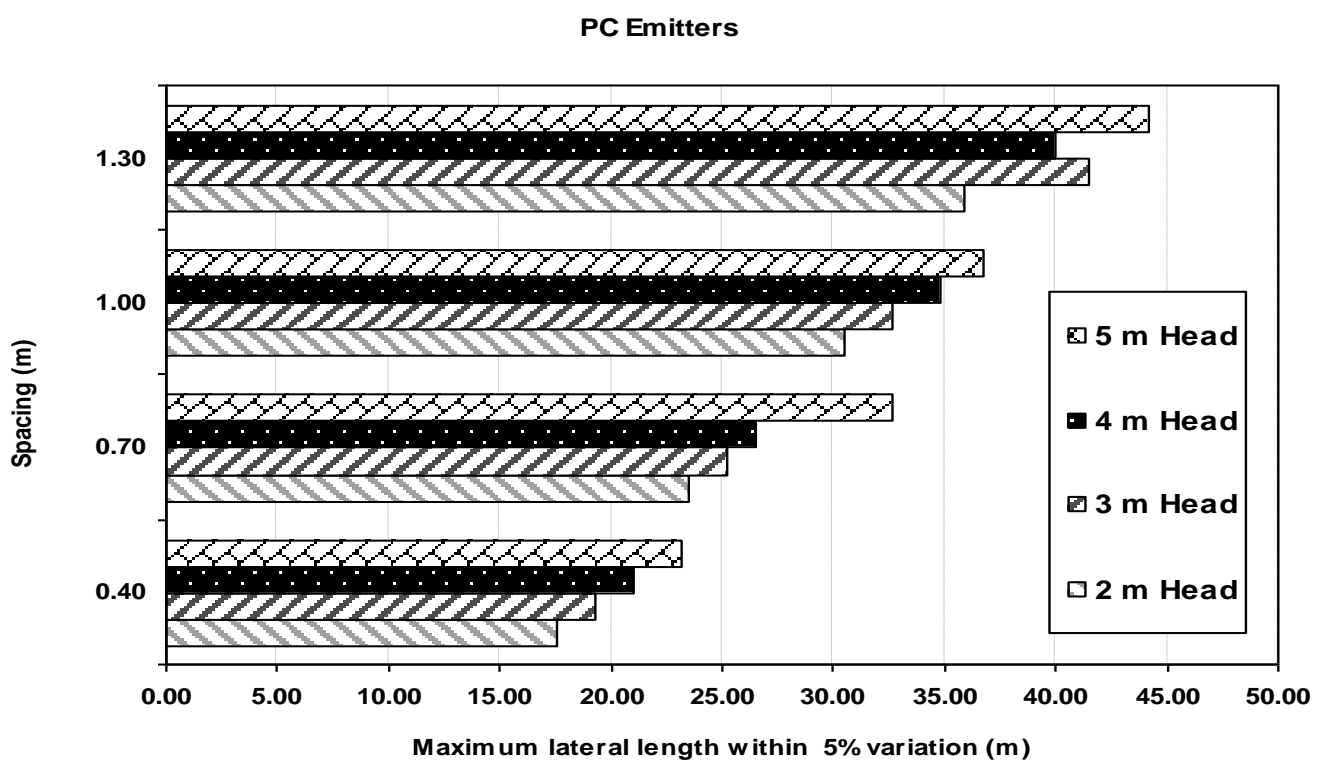

Fig. 5 Effect of Spacing on MLL - On-Line PC Emitter 


\subsection{Impact of all design factors on the MLL}

The main goal was to develop an equation that can be used for the prediction of MLL values. In other words, if the pressure head of the system, emitter spacing and emitter type is given, the MLL value can be predicted using the developed equation. The equation was calculated and listed in Table 3.

Table 3 Linear Regression for different Model parameters:

\begin{tabular}{|c|c|c|c|c|c|c|}
\hline Parameter & Value & $\begin{array}{l}\text { Standard } \\
\text { deviation }\end{array}$ & $\begin{array}{c}\text { Student's } \\
\mathbf{t}\end{array}$ & $\operatorname{Pr}>t$ & $\begin{array}{c}\text { Lower } \\
\text { bound } 95 \\
\%\end{array}$ & $\begin{array}{c}\text { Upper } \\
\text { bound } 95 \\
\%\end{array}$ \\
\hline Intercept & -7.722 & 1.289 & -5.990 & $<0.0001$ & -10.282 & -5.161 \\
\hline Replication & $\begin{array}{c}-0.019 \\
\end{array}$ & 0.290 & -0.066 & 0.947 & -0.596 & $\mathbf{0 . 5 5 8}$ \\
\hline Head (m) & 5.741 & 0.212 & 12.927 & $<0.0001$ & 2.320 & 3.163 \\
\hline Emitter Type & 2.831 & 0.479 & 12.162 & $<0.0001$ & 4.879 & 6.783 \\
\hline Spacing (cm) & 0.196 & 0.007 & 27.718 & $<0.0001$ & 0.182 & 0.210 \\
\hline $\begin{array}{l}\text { Final equation of } \\
\text { model } \\
\text { parameters }\end{array}$ & \multicolumn{6}{|c|}{ MLL $=-7.72+2.74 \times$ Head $(m)+5.83 \times$ Emitter Type $+0.19 \times$ Spacing $(\mathrm{cm})$} \\
\hline
\end{tabular}

The combine model of variables without their interactions has indicated that In-Line PC emitters perform the highest MLL. All the variables left in the model are significant at the 0.05 level. The model had an acceptable $\mathrm{R}^{2}$ values. According to the partial $\mathrm{R}^{2}$ values of variables, the highest contribution in deciding the MLL is the emitter spacing, namely, the discharge rate.

\section{Production and agronomical aspects}

For the in-line PC emitters, increasing emitter spacing decreased obtained tomato yield. Increasing spacing of emitters from 0.3 to $1.2 \mathrm{~m}$ decreased the yield by $14.6,15.1,11.0$ and $6.9 \%$ for the $2,3,4$ and $5 \mathrm{~m}$ pressure heads, respectively, at $1 \mathrm{LPH}$ discharge rate as shown in Fig. 6 and Table 4. For OPC emitters, the percentage of the decrease in yield with increasing the emitter spacing from 0.4 to $1.3 \mathrm{~m}$ were $8.5,10.8,9.1$ and $4.0 \%$, respectively. Using large emitter spacing may cause less 
penetration and more runoff, consequently, less water absorption by plant roots. As a result less yield is achieved compared to the smaller emitter spacing. Pressure heads of 4 and $5 \mathrm{~m}$ had better yield if compared to 2 and $3 \mathrm{~m}$ heads (Fig. 6).

Table 4 Effect of different system parameters on the yield of tomato

\begin{tabular}{|c|c|c|c|c|c|c|c|c|}
\hline \multirow{3}{*}{$\begin{array}{c}\text { Emitter } \\
\text { Type }\end{array}$} & \multirow{3}{*}{$\begin{array}{l}\text { Discharge } \\
\text { Rate } \\
\text { (LPH) }\end{array}$} & \multirow{3}{*}{$\begin{array}{c}\text { Spacing } \\
\text { (m) }\end{array}$} & \multicolumn{4}{|c|}{ Total Yield, Ton/ha } & \multirow{3}{*}{ Average } & \multirow{3}{*}{$\begin{array}{l}\text { Standard } \\
\text { deviation }\end{array}$} \\
\hline & & & \multicolumn{4}{|c|}{ Head, $\mathbf{m}$} & & \\
\hline & & & 2 & 3 & 4 & 5 & & \\
\hline INPC & 1 & 0.3 & 42.15 & 43.20 & 43.60 & 43.60 & 43.14 & 0.685 \\
\hline INPC & $\mathbf{1}$ & 0.6 & 38.50 & 38.45 & 42.40 & 43.50 & 40.70 & 2.623 \\
\hline INPC & $\mathbf{1}$ & 0.9 & 37.20 & 36.90 & 40.50 & 41.80 & 39.10 & 2.429 \\
\hline INPC & $\mathbf{1}$ & 1.2 & 36.00 & 36.70 & 38.80 & 40.60 & 38.00 & 2.089 \\
\hline OPC & 2 & 0.4 & 40.18 & 41.50 & 44.40 & 42.75 & 42.20 & 1.780 \\
\hline OPC & 2 & 0.7 & 37.25 & 39.50 & 40.70 & 41.80 & 39.80 & 1.950 \\
\hline OPC & 2 & 1.0 & 37.00 & 37.80 & 38.90 & 41.30 & 38.75 & 1.870 \\
\hline OPC & 2 & 1.3 & 36.75 & 37.00 & 38.75 & 41.00 & 38.40 & 1.963 \\
\hline
\end{tabular}

Interaction plot between factors Spacing $(\mathrm{m})$ and Head. M

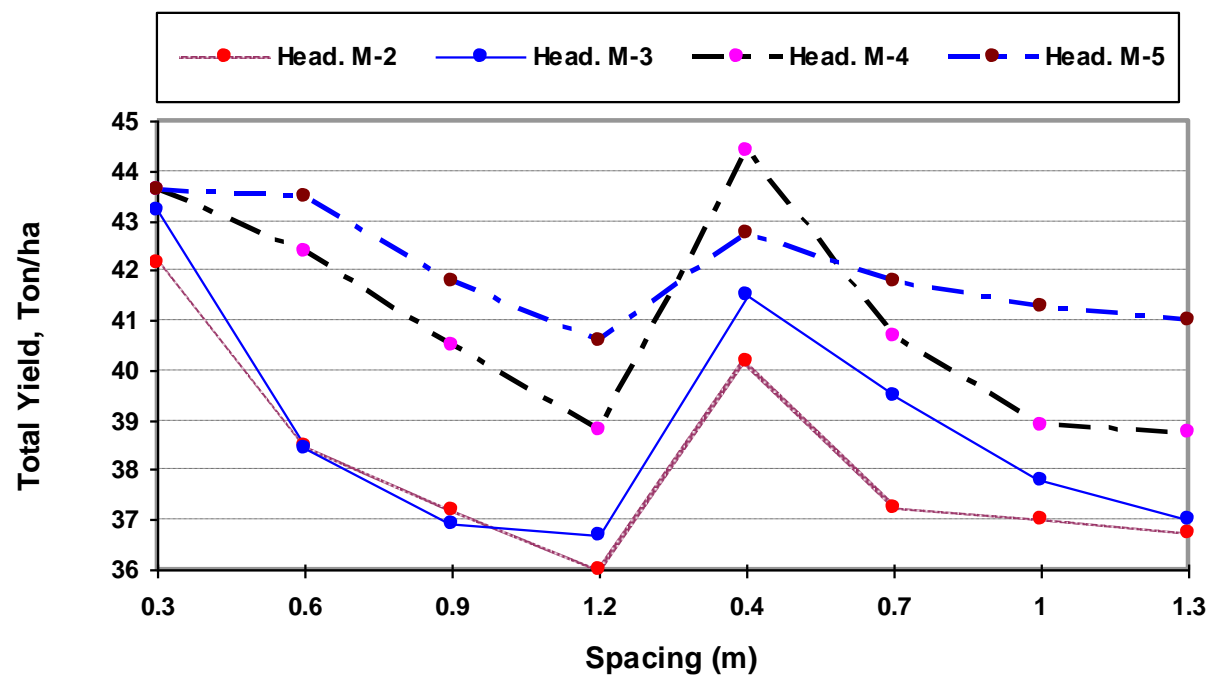

Fig. 6 Effect of emitter spacing on tomato yield under different heads

As comparison between INPC and OPC, it was clear that the total yield of tomato was high when using INPC for all head levels and all the emitter spacing (Fig.7). The average yield was 40.2 ton/ha for INPC while it was 39.8 ton/ha for OPC emitters. Maximum yield obtained within INPC was 43.6 ton/ha while minimum value of yield was 36 ton/ha for 5 and $2 \mathrm{~m}$ 
head, respectively. Based on the yield results, it is recommended to use 5 $\mathrm{m}$ head, where it increased the yield by 3.0, 11.5, 11.0 and $11.3 \%$ compared to the $2 \mathrm{~m}$ head yields for the INPC. For the OPC emitters, the $5 \mathrm{~m}$ head resulted in an increase of 6.0,10.9, 10.4 and $10.4 \%$ if compared to the $2 \mathrm{~m}$ head.

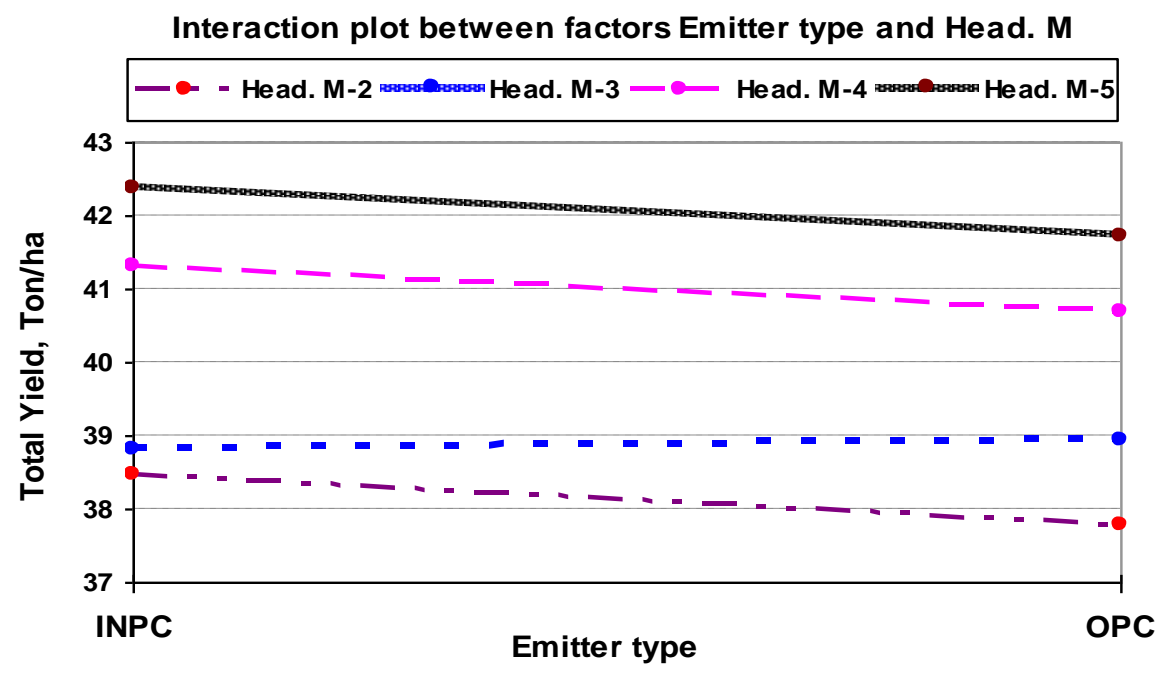

Fig. 7 Effect of emitter type on tomato yield under different heads

\section{CONCLUSIONS}

The selected design parameters of emitter spacing, head of the system, emitter discharge rate and emitter type have significant influence on the design of the maximum lateral length within a $5 \%$ flow variation in a gravity-fed trickle irrigation system. The developed model, equation, with all the design parameters and their interactions indicated that the impact of spacing increased significantly if compared to considering the complete model without interactions. However, it is important to validate the obtained equations under different field conditions, emitter types and pressure heads for versatile use and more accurate limits. However, the given set of equations will enable farm owners to design a gravity-fed trickle irrigation system if the design parameters and field conditions are similar to the conditions of this experiment. Also, testing the effect of different design variables on production and agronomical aspects gave adequate results as guide to install the suitable elements related the 
planted crop to obtain efficient trickle irrigation system in greenhouses with minimum cost as adaptable system for smallholders.

\section{REFERENCES}

Bralts, V. F.; I. P. Wu and M. Giltin (1982). Emitter plugging and drip irrigation lateral line hydraulics. Trans. ASAE 25 (5), p: $1274-81$.

Berihun, B. (2011). Effect of mulching and amount of water on the yield of tomato under drip irrigation. Journal of Horticulture and Forestry 3 (7), p: 200-206.

Cheema, D. S.; P. Kaur and S. Kaur (2005). Off-season cultivation of tomato under nethouse conditions. Paper Presented at VII Int. Symp. on Protected Cult. Mild Winter Climates: Prod. Pest Management and Global Competition. Acta Hort., 659, p: 1-14.

Harmanto; V. M. Salokhe and M. S. Babel (2004). Water requirement of drip irrigated tomatoes grown in greenhouse in tropical environment. Agric.Water Managt. 71, p: 225-242.

IDE, International Development Enterprises (2010). Ideal micro irrigation systems. Technical manual, IDE, Lakewood, CO 80215, USA, P: 3-8.

Jaiswal, A. P.; V. V. Aware and A. G. Powar ( 2001). Field Evaluation of Hydraulic Performance of Drip Irrigation System. Micro Irrigation. Central board of Irrigation and Power, p:1, 3 New Delhi, India.

Malash, N. M.; T. J. Flowers and A. R. Ragab (2005). Effect of irrigation systems and water management practices using saline and non-saline water on tomato production. Agricultural Water Management 78, p: 25-38.

Michel, A. M. (1978). Irrigation Theory and Practice. Viscus Publishing House (Pvt) Ltd., 576 Masjid Road, Jangparc, New Delhi. Chapter 3, p: $216-222$.

Nour El Din, M. (2007). Energy for Irrigation Water in Egypt. Plan Bleu/MEDITEP Regional Workshop, Water, Energy and Climate Change in the Mediterranean, Carthage, Tunisia. 17 December 2007.

Shedeed, S. I.; S. M. Zaghloul, A. A. Yassen (2009). Effect of Method and Rate of Fertilizer Application under Drip Irrigation on Yield and Nutrient Uptake by Tomato. Ozean Journal of Applied Sciences 2 (2), p: 139-147. 


\section{الملخص العربى}

\section{تصميم وثأثير استخدام نظام ري بالتثقيط في البيوث المحمية بمنطقة الدلتا في مصر في مر}

د. احمد محمد الشيخه* د. رشاد عزيز حجازي*** د. ضياء محمد الشيخه***

أجريت الدر اسة بهدف الوصول الي افضل مكونات لثبكات الري بالتنقيط و التي تعمل بالتانثر

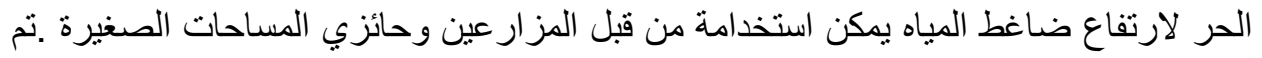

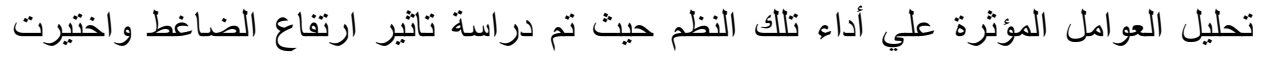

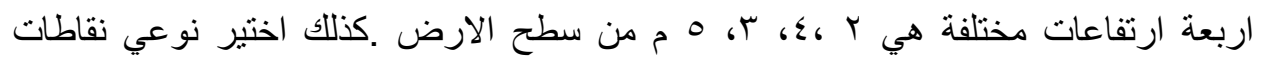

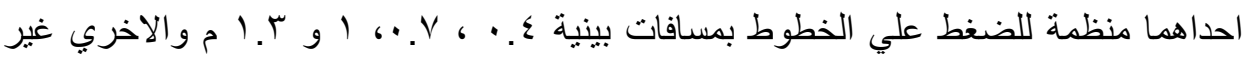

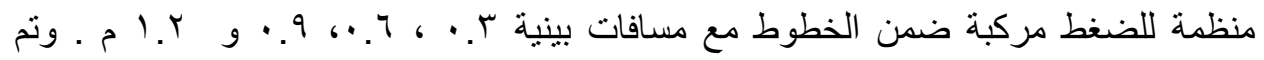

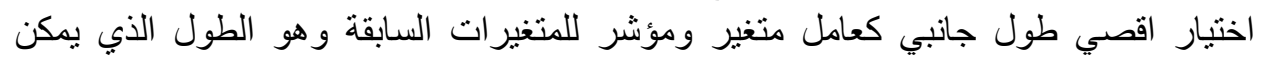

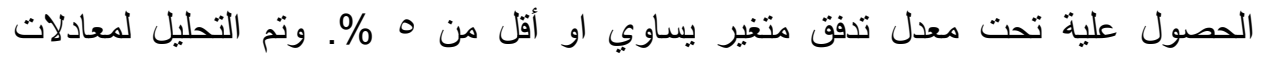
ومعاملات الانحدار لكل متغير علي حدا وكذلك دراسة المتغيرات معا في وجود و وعدم وجود

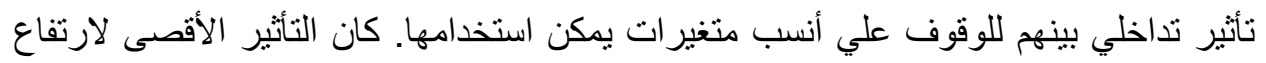

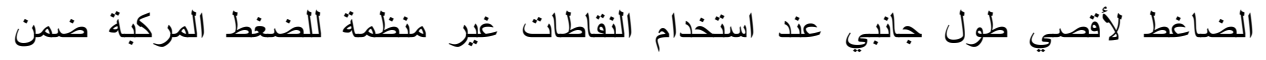

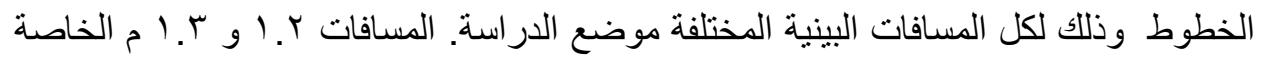

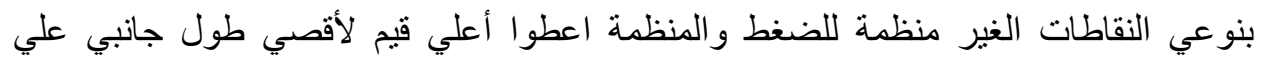

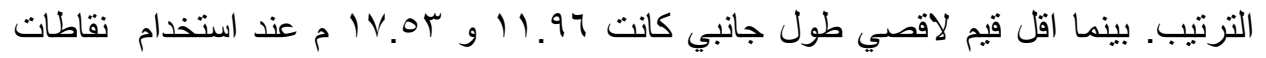

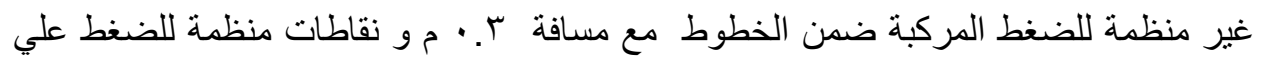

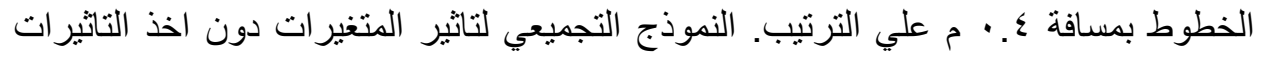

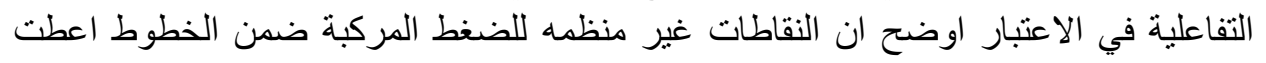

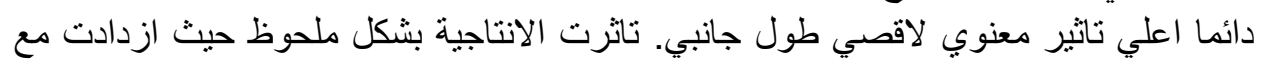

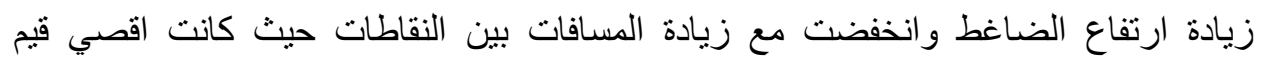

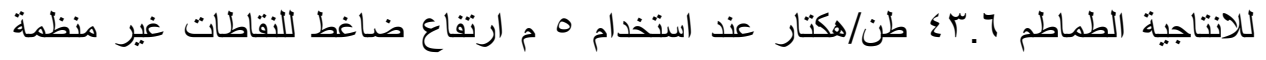

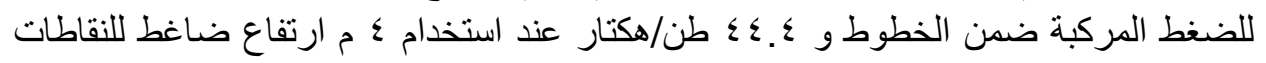

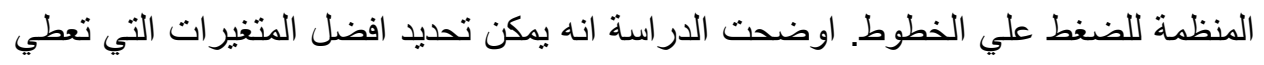
اقصي طول جانبي للخطوط في مسافة معينة تحت ارتفاعات مختلفة لضاغط المياه وبالتالي يمكن استخدامها ايضا تحت ظروف تشغيل مختلفة تناسب الكثير من المز ارعين.

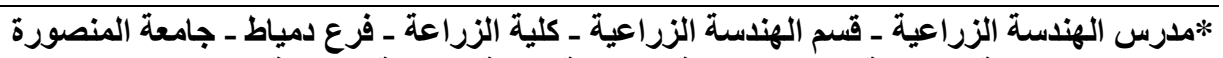

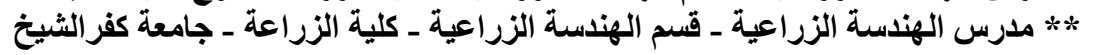

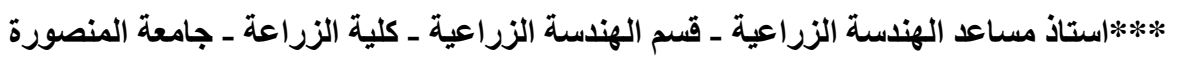

